\title{
Outbreak of anaplasmosis associated with the presence of different Anaplasma marginale strains in dairy cattle in the states of Sáo Paulo and Goiás, Brazil
}

\author{
Surto de anaplasmose associado com a presença de diferentes cepas de \\ Anaplasma marginale em gado leiteiro dos estados de São Paulo e Goiás, Brasil \\ Rosangela Zacarias Machado ${ }^{1 *}$; Jenevaldo Barbosa da Silva ${ }^{1}$; Marcos Rogério André1; Luiz Ricardo Gonçalves; \\ Carlos Antonio Matos ${ }^{1,2}$; Dasiel Obregón ${ }^{1,3}$
}

\begin{abstract}
${ }^{1}$ Departamento de Patologia Veterinária, Faculdade de Ciências Agrárias e Veterinárias - FCAV, Universidade Estadual Paulista "Júlio de Mesquita Filho" - UNESP, Jaboticabal, SP, Brasil

${ }^{2}$ Direcção de Ciências Animais, Maputo, Moçambique

${ }^{3}$ Universidad Agraria de La Habana - UNAH, San José de las Lajas, Mayabeque, Cuba
\end{abstract}

Received August 18, 2015

Accepted October 19, 2015

\begin{abstract}
The present study reports the genetic diversity of Anaplasma marginale during anaplasmosis outbreaks in rural properties of the states of Goiás and Sáo Paulo, Brazil. Mortality rates of 3.5\% (37/1,050) in calves, 4.7\% (45/954) in heifers and $1.1 \%(25 / 2,200)$ in lactating cows were observed in a cattle herd of the municipality of Mambaí, state of Goiás, central-western Brazil. In a cattle herd from the municipality of Lins, state of São Paulo, in southeastern Brazil, none of the animals died, despite presenting clinical signs suggestive of bovine anaplasmosis and exhibiting a drastic decrease in milk production. Thus, blood samples were collected from 100 animals with clinical signs suggestive of bovine anaplasmosis in the municipalities of Mambaí and Lins. Based on the microsatellite structure of the MSP1a of $A$. marginale, the genotypes $\mathrm{E}$ and $\mathrm{H}$ were observed in Lins, and the $\mathrm{C}, \mathrm{D}$ and $\mathrm{E}$ genotypes were found in Mambaí. The analysis of the tandem repeat structures of the MSP1a showed nine different strains $\left(\tau-10-15, \alpha-\beta^{2}, \alpha-\beta^{3}-13, \alpha-\beta^{2} 192, \tau-\beta-100\right.$, $\alpha-\beta^{2}-\Gamma, 193-\beta-100,191-13-\Gamma$ and 191-13-18) in Lins and two $\left(\alpha-\beta^{3}-\Gamma\right.$ and $\left.E-F-\varphi^{2}-F^{2}\right)$ in Mambaí. Three new tandem repeats of MSP1a (191, 192 and 193) were described. The $\tau-10-15$ and $\alpha-\beta^{3}-\Gamma$ strains were predominantly associated with the occurrence of clinical anaplasmosis and mortality in calves, heifers and lactating cows.
\end{abstract}

Keywords: Anaplasmosis, Brazil, dairy herd, genotypes, MSP1a, outbreaks.

\section{Resumo}

O presente estudo relata a diversidade genética de Anaplasma marginale durante surtos de anaplasmose bovina no Brasil em propriedades localizadas nos Estados de Goiás e São Paulo. No rebanho bovino de Mambaí, Estado de Goiás, Centro-oeste do Brasil, observaram-se taxas de mortalidade de 3,5\% (37/1050) nos bezerros; 4,7\% (45/954) nas novilhas e 1,1\% (25/2200) nas vacas em lactação. No rebanho bovino de Lins, Estado de São Paulo, Sudeste do Brasil, embora os animais tenham apresentado sinais clínicos sugestivos de anaplasmose bovina, culminando em reduçáo drástica da produção leiteira, nenhum animal veio a óbito. Assim, amostras de sangue de 100 bovinos com sinais clínicos sugestivos de anaplasmose foram coletadas em Mambaí-GO e Lins-SP. Baseando-se na estrutura do microssatélite da MSP1a de A. marginale, observou-se a presença dos genótipos $\mathrm{E}$ e $\mathrm{H}$ em Lins e C, D e E em Mambaí. A análise da estrutura em "tandem repeats" da MSP1a mostrou nove diferentes estirpes $\left(\tau-10-15, \alpha-\beta^{2}, \alpha-\beta^{3}-13, \alpha-\beta^{2} 192, \tau-\beta-100, \alpha-\beta^{2}-\Gamma\right.$, 193- $\beta-100,191-13-\Gamma$ e 191-13-18) em Lins e duas $\left(\alpha-\beta^{3}-\Gamma\right.$ e E-F- $\left.\varphi^{2}-F^{2}\right)$ em Mambaí. Três novos "tandem repeats" da MSP1a (191, 192 e 193) foram descritos. Foi observado predomínio das estirpes $\tau-10-15$ e $\alpha-\beta 3-\Gamma$ associado à ocorrência de anaplasmose clínica e mortalidade em bezerras, novilhas e vacas em lactação.

Palavras-chave: Anaplasmose, Brasil, rebanho leiteiro, genótipos, MSP1a, surtos. 


\section{Introduction}

Anaplasma marginale is a pathogen transmitted by ticks that belongs to the Anaplasmataceae family, order Rickettsiales (DUMLER et al., 2001). This rickettsia is a gram negative, obligate intracellular bacterium that can be biologically transmitted by ticks, can be mechanically transmitted by bloodsucking flies and fomites contaminated with infected blood, and, less commonly, can be transmitted via the placenta (KOCAN et al., 2010; AUBRY \& GEALE, 2011)

Brazil is considered an endemic area for anaplasmosis in cattle (VIDOTTO et al., 2006; POHL et al., 2013), and the infection of cattle by multiple strains of $A$. marginale has recently been reported in the country (POHL et al., 2013; SILVA et al., 2015a, b). The global distribution and variation in pathogenicity of A. marginale are associated to the genetic diversity and variability of this bacterium (FUENTE et al., 2007). The genetic diversity of $A$. marginale strains is high in cattle in endemic regions worldwide (PALMER et al., 2001; FUENTE et al., 2007; CABEZAS-CRUZ et al., 2013; SILVA et al., 2015a).

The major surface proteins (MSPs) MSP5, MSP4 and MSP1a have been widely used for molecular characterization of A. marginale (AUBRY \& GEALE, 2011). MSP1 is an adhesin important to bovine erythrocytes and tick cells. The protein contains tandem repeats that are involved in pathogen-host interaction, which provides relevant information about the $A$. marginale phenotypes transmitted by ticks (FUENTE et al., 2003a). Furthermore, analysis of the repeated sequences of MSP1 alpha has allowed the identification of $A$. marginale strains worldwide (CABEZAS-CRUZ et al., 2013). Despite the genetic diversity of MSP1a, this gene is considered a stable genetic marker, which is conserved in infections in cattle and ticks (PALMER et al., 2001; BOWIE et al., 2002; FUENTE et al., 2003b).

Among the different strains of $A$. marginale identified worldwide, some have been associated with the occurrence of anaplasmosis outbreaks. The $\alpha-\beta^{3}-\Gamma$ and $\tau-10-15$ strains have been previously described in outbreaks of bovine anaplasmosis in Mexico (ALMAZÁN et al., 2008) and Argentina (RUYBAL et al., 2009). In addition, the 72-62-61 strain has been reported as the most common in a cattle herd from the state of Minas Gerais, Brazil (POHL et al., 2013). In Brazil, significant variations in the MSP1a tandem repeats of strains of $A$. marginale have been found in the states of Paraná (VIDOTTO et al., 2006), Minas Gerais (FUENTE et al., 2004; POHL et al., 2013), Rio de Janeiro (SILVA et al., 2015a) and Sáo Paulo (SILVA et al., 2015b). In MSP1a tandem repeats of strains of $A$. marginale described in Brazil, the most frequent sequences are 16, $\alpha, \tau$ in Paraná (VIDOTTO et al., 2006), 72 and $\alpha$ in Minas Gerais (POHL et al., 2013), 4 and $\tau$ in Rio de Janeiro (SILVA et al., 2015a) and, $\alpha$ and $\beta$ in Sáo Paulo (SILVA et al., 2015b). The present study aimed to understand the genetic diversity of $A$. marginale during an outbreak of bovine anaplasmosis in rural properties located in the municipalities of Lins, state of São Paulo (southeastern), and Mambaí, state of Goiás (central-western), Brazil.

\section{Materials and Methods}

\section{Area and animals}

A cross-sectional study was performed in rural properties of the municipalities of Lins (latitude: 21 40' 43" S, Longitude: 490 44' 33” W and altitude: $437 \mathrm{~m}$ ), state of São Paulo (southeastern) in October 2012, and Mambaí (Latitude: 14 29' 16” S, longitude: 4606'47” W and altitude: $709 \mathrm{~m}$ ), state of Goiás (central-western), in December 2012, Brazil. The properties located in the municipality of Lins and Mambaí had a cattle herd of 1,010 Holstein animals and 4,204 Holstein, Jersey and crossbred animals, respectively. Fifty animals with clinical signs suggestive of bovine anaplasmosis were evaluated on each property. The animals from the property located in Mambaí were treated during the anaplasmosis outbreak with the following acaricides: Combo (cypermethrin + chlorpyrifos + piperonyl butoxide, Hertape, Brazil), Acatak (fluazuron, Novartis, Brazil) and Fluatac (fluazuron + abamectin, Ouro Fino, Brazil), according to the manufacturer's recommendation.

\section{Blood samples}

Ethylenediamine tetraacetic acid (EDTA)-blood samples of 50 animals of each property were collected from the caudal or jugular veins of individual cattle. Serum samples were prepared from blood samples that were collected without EDTA, incubated at room temperature for $1 \mathrm{~h}$ and then centrifuged at $1000 \times \mathrm{g}$ for 15 minutes. Additionally, Giemsa-stained blood smears were prepared for microscopic examination. EDTA-blood and serum samples were stored at $-20{ }^{\circ} \mathrm{C}$. DNA was extracted from $200 \mu \mathrm{L}$ of each of the 100 whole-blood samples using a QIAamp DNA Blood Mini kit (Qiagen, Madison, WI, USA) according to the manufacturer's instructions.

\section{Enzyme-linked immunosorbent assay (ELISA) and indirect fluorescent antibody test (IFAT)}

ELISA and IFAT were performed as previously described by Machado et al. (1997) and Andrade et al. (2004). An A. marginale isolate from a calf in Jaboticabal, state of São Paulo, Brazil, was used to infect a calf for crude ELISA and IFAT antigen production (ANDRADE et al., 2004). For this purpose, a 3-month-old splenectomized calf was inoculated with $200 \mathrm{~mL}$ of A. marginale-infected blood $\left(1.0 \times 10^{7}\right.$ infected erythrocytes $\left./ \mathrm{mL}\right)$. The rickettsemia peak $\left(1.0 \times 10^{7} \mathrm{~A}\right.$. marginale-infected erythrocytes $\left./ \mathrm{mL}\right)$ was observed 7 days after the experimental infection. After the blood had been collected and processed for crude ELISA/IFAT antigen production (MACHADO et al., 1997), the experimentally infected animal was treated with oxytetracycline administered intramuscularly $(20 \mathrm{mg} / \mathrm{kg})$.

\section{Polymerase chain reaction (Semi-Nested-PCR and quantitative real time PCR)}

A total of 100 DNA samples were analyzed by quantitative real-time PCR (qPCR) reactions according to Carelli et al. (2007) for the mspla gene. qPCR positive samples were additionally 
submitted to a semi-Nested PCR (nPCR) targeting mspla sequence (LEW et al., 2002). The nPCR reactions were performed using the primers $1733 \mathrm{~F}$ (5'-TGT GCTTATGGCAGACATTTCC-3'), 3134R (5'-TCACGGTCAAAACCTTTGCTT ACC-3') and 2957R (5'-AAACCTTGTAGCCCC AAC TTATCC-3'). Thus, the primers used were $1733 \mathrm{~F}$ and $3134 \mathrm{R}$ in the first reaction and, $1733 \mathrm{~F}$ and $2957 \mathrm{R}$ in the second reaction.

\section{Sequence of $A$. marginale mspla microsatellite}

A microsatellite is located at the 5'-untranslated region (UTR) of the mspla gene between the putative Shine-Dalgarno (GTAGG) sequence and the translation initiation codon (ATG) (Fuente et al., 2001). The microsatellite structure is GTAGG (G/ATTT)m (GT)n T ATG (ESTRADA-PEÑA et al., 2009). An analysis of the repeated sequences was performed according to the nomenclature proposed by Fuente et al. (2007). The SD-ATG distance was calculated according to the formula:

$$
(4 \times m)+(2 \times n)+1
$$

\section{Phylogenetic analysis}

For mspla phylogenetic analysis, nucleotide sequences were aligned with MUSCLE (v3.7) configured for high precision (EDGAR, 2004) followed by removal of the ambiguous regions with Gblocks (v0.91b) (CASTRESANA, 2000). After alignment, regions with gaps were removed. Phylogenetic trees were reconstructed using the maximum likelihood (ML) and neighbor joining (NJ) methods as implemented in PhyML (v3.0 aLRT) (ANISIMOVA \& GASCUEL, 2006) and PHYLIP (v3.66) (FELSENSTEIN, 1989), respectively. The reliability of the internal branches of the ML and NJ trees was assessed using the bootstrapping method (1,000 bootstrap replicates). Graphical representation and editing of the phylogenetic trees were performed with TreeDyn (v198.3) (CHEVENET et al., 2006). Detection of selection pressure on individual codons was calculated using two methods: single likelihood ancestor counting (SLAC) and fixed effects likelihood (FEL) implemented in the Datamon-key webserver (DELPORT et al., 2010).

\section{Statistical analysis}

The frequencies of positive animals for $A$. marginale were compared via the Fisher's exact test, with 95\% confidence level. Associations between the prevalence and its possible influencing determinants were measured by means of odds ratios (ORs). The operational procedures were performed with the aid of the statistical software R Foundation for Statistical Computing, version 2.12.2 (2011).

\section{Results}

\section{Cattle mortality rate during the anaplasmosis outbreak}

An overall mortality of $2.5 \%(107 / 4,204)$ was observed in the cattle herd from the municipality of Mambaí (state of Goiás) during the anaplasmosis outbreak (Figure 1), with 3.5\% (37/1,050) of the calves, $4.7 \%(45 / 954)$ of the heifers and $1.1 \%(25 / 2,200)$ of the lactating cows dying. Animals presented fever, anemia and reduction in milk production. In contrast, in the property located in the municipality of Lins (state of Sáo Paulo), none of the animals died, although they presented apparent clinical signs of bovine anaplasmosis (fever, anemia and reduction in milk production) and positive results in the blood smear examination and the qPCR. In the property located in the municipality of Mambaí, the heifers and calves were four and three times, respectively, more likely to die from anaplasmosis than lactating cows (Figure 1).

\section{Anaplasma marginale detection and rickettsemia (qPCR) in dairy cattle}

The prevalence of $A$. marginale in the samples from the municipalities of Lins and Mambaí was $84 \%$ and $34 \%$ by blood smear, $52 \%$ and $50 \%$ by IFAT, $58 \%$ and $54 \%$ by ELISA and $94 \%$ and $38 \%$ by qPCR, respectively (Table 1 ). The absolute quantification of $A$. marginale assessed by qPCR ranged from $7.77 \times 10^{2}$ to $1.97 \times 10^{7}$ in animals sampled in Lins and

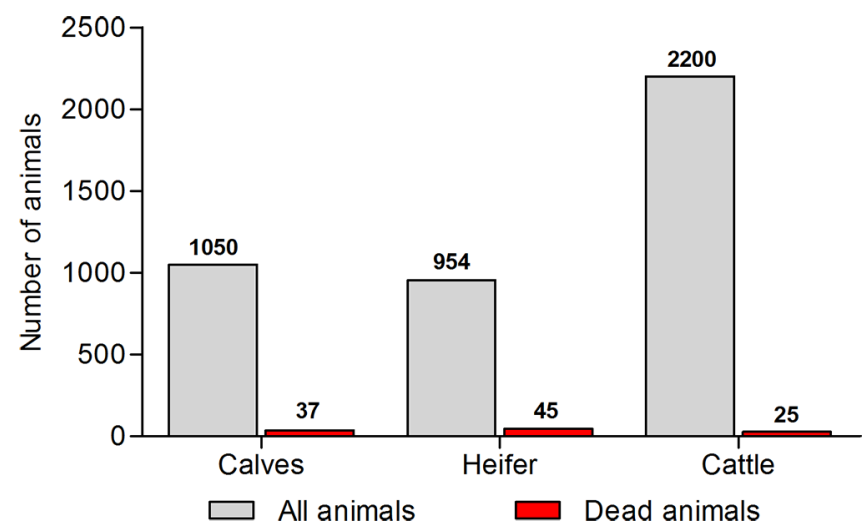

Figure 1. Animal mortality rate during the anaplasmosis outbreak in a rural property located in the municipality of Mambaí, state of Goiás, Central-West Region, Brazil. A total of 4,204 animals were evaluated including 1,050 calves, 954 heifers and 2,200 cows. The death cause was confirmed as anaplasmosis only for animals with apparent clinical signs and positive results in the blood smear and/or PCR assays.

Table 1. Frequency (\%) of animals positive for Anaplasma marginale. Anaplasma marginale was detected by direct examination (blood smears), serological tests (ELISA/IFAT) and molecular analysis (qPCR) of samples from naturally infected dairy cattle in São Paulo and Goiás states, Brazil.

\begin{tabular}{cccccc}
\hline \multirow{2}{*}{ Local } & \multicolumn{3}{c}{ Frequency of positivity (\%) } & \multicolumn{2}{c}{$\begin{array}{c}\text { Rickettsemia qPCR* } \\
\text { Mean } \pm \text { Standard Deviation }\end{array}$} \\
\cline { 2 - 5 } & Blood smear & ELISA & IFAT & qPCR & $7.77 \times 10^{6}-1.97 \times 10^{7}$ \\
Lins SP & $84 \%$ & $58 \%$ & $52 \%$ & $94 \%$ & $1,82 \times 10^{3}-6.40 \times 10^{3}$ \\
\hline Mambaí GO & $34 \%$ & $54 \%$ & $50 \%$ & $38 \%$ & $1.8 \%$ \\
\hline
\end{tabular}

${ }^{*}$ mspla copies per $\mathrm{mL}$ of blood in all positive animals. 
$1.27 \times 10^{1}$ to $1.49 \times 10^{4}$ in animals sampled in Mambaí. All animals with positive results by blood smear were also positive by qPCR. The ELISA showed $89.6 \%$ and $92.6 \%$ agreement with the IFAT in the samples from the municipalities of Lins and Mambaí, respectively. Variations in the serological and molecular prevalence of $A$. marginale were observed in calves, heifers, and pregnant and lactating cows (Table 2). In Mambaí, the ELISA and qPCR prevalence of $A$. marginale was significantly higher in calves $(\mathrm{p}<0.04)$ and heifers $(\mathrm{p}<0.05)$ than in pregnant cows. Additionally, lactating cows showed a lower molecular prevalence of $A$. marginale than calves and heifers $(\mathrm{p}<0.03)$.

\section{Analysis of $A$. marginale MSP1a sequences in cattle}

According to the structure of the MSP1a microsatellite of A. marginale, the genotypes $\mathrm{E}$ and $\mathrm{H}$ were observed in the samples from Lins and the genotypes C, D and E were found in cattle

Table 2. Frequency (\%) of calves, heifer, pregnant and lactation cows positive for Anaplasma marginale. Anaplasma marginale was detected by direct examination (blood smears), serological tests (ELISA/IFAT) and molecular analysis (PCR) of samples from naturally infected dairy cattle in Goiás State, Brazil.

\begin{tabular}{lcccc}
\hline \multirow{2}{*}{ Class } & \multicolumn{4}{c}{ Frequency of positivity (\%) } \\
\cline { 2 - 5 } & $\begin{array}{c}\text { Blood } \\
\text { smear }\end{array}$ & IFAT & ELISA & qPCR \\
\hline Calves $(\mathrm{n}=10)$ & 80 & 60 & 60 & 50 \\
Heifer (n=20) & 85 & 60 & 65 & 50 \\
$\begin{array}{l}\text { Pregnant cow } \\
(\mathrm{n}=10)\end{array}$ & 70 & 20 & 20 & 20 \\
$\begin{array}{l}\text { Lactation cow } \\
(\mathrm{n}=10)\end{array}$ & 50 & 50 & 60 & 20 \\
\hline
\end{tabular}

from Mambaí (Table 3). The analysis of the MSP1a tandem repeats structure showed nine different $A$. marginale strains $\left(\tau-10-15, \alpha-\beta^{2}, \alpha-\beta^{3}-13, \alpha-\beta^{2} 192, \tau-\beta-100, \alpha-\beta^{2}-\Gamma, 193-\beta-100\right.$, 191-13- $\Gamma$ and 191-13-18) in cattle from Lins and two strains $\left(\alpha-\beta^{3}-\Gamma\right.$ and $\left.\mathrm{E}-\mathrm{F}-\varphi^{2}-\mathrm{F}^{2}\right)$ in cattle from Mambaí (Table 3$)$. This is the first report of the $\mathrm{H}$ genotype and the E-F- $\varphi^{2}-\mathrm{F}^{2}$ strain in Brazil. Three new tandem repeats, 191, 192 and 193, were described in the present study (Figure 2). The tandem repeats 191 and $\tau$ only differed by the amino acid located at position 28: leucine (L) was observed at the tandem repeat $\tau$, whereas serine $(S)$ was found at the tandem repeat 191 . The tandem repeats 192 and $\Gamma$ differed only by the amino acid located at position 13, serine (S) and arginine (R) were found at tandem repeats $\Gamma$ and 192 , respectively. The tandem repeats 193 and 4 differed by two amino acids located at the positions 5 and 18, serine (S) and glutamine (Q) were observed at the tandem repeat 4, and threonine (T) and proline $(\mathrm{P})$ were observed at the tandem repeat 193.

\section{Phylogenetic analysis}

The phylogenetic analysis identified four distinct groups among the studied samples (Figure 3). The analysis (NJ and ML) produced similar topologies and the same relationships for all major clusters that were identified in the present study and represented in the NJ tree. The phylogenetic tree was constructed based on the sequence of the MSP1a of $A$. marginale identified in cattle from the property located in Lins $\left(\tau-10-15, \alpha-\beta^{2}, \alpha-\beta^{3}-13, \alpha-\beta^{2}-192\right.$, $\alpha-\beta-100,193-\beta-100,191-13-\Gamma$ and 191-13-18) and Mambaí $\left(\alpha-\beta^{3}-\Gamma\right.$ and $\left.\mathrm{E}-\mathrm{F}-\varphi^{2}-\mathrm{F}^{2}\right)$. In addition to the strains identified in the present study, $A$. marginale strains isolated in Brazil (states of Minas Gerais, Paraná, São Paulo and Rio de Janeiro), South Africa (SA), Argentina (Ar), the United States (USA), the Philippines (Ph),

Table 3. Organization of the MSP1a tandem repeats and Anaplasma marginale strains isolated in naturally infected dairy cattle on farms located in the municipalities of Lins, state of São Paulo, and Mambaí, state of Goiás, Brazil. Anaplasma marginale strain identification is based on MSP1a, including locality/microsatellite genotype - (tandem repeats structure); SD-ATG distance; and rickettsemia in the strains identified in cattle.

\begin{tabular}{|c|c|c|c|c|c|}
\hline $\begin{array}{c}\text { Sructure of MSP1a tandem } \\
\text { repeats }\end{array}$ & Genotype & $\mathbf{m}$ & $\mathbf{n}$ & $\begin{array}{l}\text { SD-ATG distance } \\
\text { (nucleotide) }\end{array}$ & $\begin{array}{c}\text { Rickettsemia* } \\
\text { (msp } 1 a \text { copies } / \mathrm{mL})\end{array}$ \\
\hline Lins SP/7 ( $\tau-10-15)$ & $\mathrm{H}$ & 3 & 6 & 25 & $7.75 \times 10^{5}$ \\
\hline Lins $S P / 10(\tau-10-15)$ & $\mathrm{H}$ & 3 & 6 & 25 & $2.02 \times 10^{7}$ \\
\hline Lins $S P / 16(\tau-10-15)$ & $\mathrm{H}$ & 3 & 6 & 25 & $5.95 \times 10^{3}$ \\
\hline Lins SP/11 (191-13-18) & $\mathrm{E}$ & 2 & 7 & 23 & $6.34 \times 10^{5}$ \\
\hline Lins $S P / 12\left(\alpha-\beta^{2}\right)$ & $\mathrm{E}$ & 2 & 7 & 23 & $7.29 \times 10^{5}$ \\
\hline Lins $S P / 110\left(\alpha-\beta^{3}-13\right)$ & $\mathrm{E}$ & 2 & 7 & 23 & $6.13 \times 10^{4}$ \\
\hline Lins $S P / 703\left(\alpha-\beta^{2}-192\right)$ & $\mathrm{E}$ & 2 & 7 & 23 & $9.24 \times 10^{4}$ \\
\hline Lins SP/1136 $(\tau-\beta-100)$ & $\mathrm{E}$ & 2 & 7 & 23 & $1.42 \times 10^{6}$ \\
\hline Lins SP/1228 $\left(\alpha-\beta^{2}-\Gamma\right)$ & $\mathrm{E}$ & 2 & 7 & 23 & $1.21 \times 10^{5}$ \\
\hline Lins $S P / 1450(193-\beta-100)$ & $\mathrm{E}$ & 2 & 7 & 23 & $6.42 \times 10^{3}$ \\
\hline Lins SP/1453 (191-13-Г) & $\mathrm{E}$ & 2 & 7 & 23 & $2.53 \times 10^{3}$ \\
\hline Mambaí GO/1017B $\left(\alpha-\beta^{3}-\Gamma\right)$ & $\mathrm{E}$ & 2 & 7 & 23 & $4.74 \times 10^{3}$ \\
\hline Mambaí GO/1568B $\left(\alpha-\beta^{3}-\Gamma\right)$ & $\mathrm{D}$ & 2 & 6 & 21 & $1.49 \times 10^{4}$ \\
\hline $\begin{array}{l}\text { Mambaí GO/1806B } \\
\left(\mathrm{E}-\mathrm{F}-\varphi^{2}-\mathrm{F}^{2}\right)\end{array}$ & $\mathrm{C}$ & 2 & 5 & 19 & $3.57 \times 10^{3}$ \\
\hline
\end{tabular}

$\left(\mathrm{E}-\mathrm{F}-\varphi^{2}-\mathrm{F}^{2}\right)$

* mspla copies per mL of blood in all positive animals. The microsatellite (sequence in bold) was located between the Shine-Dalgarno (SD; sequence in brackets) and the translation initiation codon (ATG) with the structure: GTAGG $($ G/A TTT) $\boldsymbol{m}(\mathbf{G T}) \boldsymbol{n}$ T ATG. The SD-ATG distance was calculated in nucleotides as $(4 \times m)+(2 \times n)+1$. 

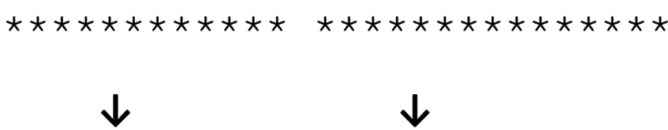

\section{3}

herds, causing clinical cases of bovine anaplasmosis in the world. The present study reports two bovine anaplasmosis outbreaks. One outbreak occurred in the municipality of Mambaí, state of Goiás, Brazil, causing the death of 107 animals (37 calves, 45 heifers and 25 lactating cows). The other anaplasmosis outbreak occurred in a rural property located in the municipality of Lins, state of São Paulo, Brazil; no animals died, but lactating cows showed a drastic reduction in milk production.

Prior to the present study, the animals of the property located in the municipality of Mambaí were kept in an alternate grazing system with center pivot irrigation. In this system, the animals had virtually no contact with ticks. However, due to a prolonged food shortage during the month of February 2012, some animals were transferred to an area of silvopasture, and when returned to the original area, they were infested with ticks. The bovine anaplasmosis outbreak began 14 to 20 days after the animals were transferred back to the center pivot irrigation system. Furthermore, due to the amount of feces accumulated during mechanical milking, a high number of flies were present at the fluid treatment station. Thus, two explanations exist for the occurrence of a bovine anaplasmosis outbreak on the property located in Mambaí: (1) mechanical transmission of $A$. marginale by the high number of Stomoxys calcitrans flies originated from larvae that developed in faeces, accumulated in the environment and/or (2) the biological transmission of $A$. marginale by Rhipicephalus (Boophilus) microplus after the animals were placed in an area infested with cattle tick. Thus, in both scenarios, clinical cases of anaplasmosis and animal mortality occurred because animals were kept for a long period in a production system with no contact with $A$. marginale and, then, were exposed to the pathogen through tick and/or fly infestations. In contrast, in the rural property located in the municipality of Lins, the animals studied were from Uruguay and had been newly introduced into the herd. The introduction of infected animals into the herd has been proposed as a source of genetic diversity of $A$. marginale worldwide (FUENTE et al., 2007).

Anaplasma marginale prevalence was 94\% (47/50) and 38\% $(19 / 50)$ according to the qPCR in bovines from the properties located in Lins and Mambaí, respectively. However, of these samples, only 23\% (11/47) of the animals from Lins and 16\% (3/19) of the animals from Mambaí were positive according to nPCR. In the present study, only samples with absolute quantification greater than $2.53 \times 10^{3}$ in the qPCR were positive by $\mathrm{nPCR}$ and subsequently sequenced. Thus, the different results observed in the nPCR and qPCR assays may have occurred due to differences in the level of rickettsiae in the samples and differences in the sensitivity of the PCR assays (FUENTE et al., 2001). In the present study, the samples negative by $\mathrm{nPCR}$ showed variation of $1.27 \times 10^{1}$ to $3.83 \times 10^{2}$ in absolute quantification by qPCR.

The results of the present study showed that the genetic diversity of the MSP1a of $A$. marginale was low among the cattle sampled in the property located in Mambaí, and only two strains were identified $\left(\alpha-\beta^{3}-\Gamma\right.$ and $\left.E-F-\varphi^{2}-F^{2}\right)$. In the microsatellite analysis, the genotypes $\mathrm{C}, \mathrm{D}$ and $\mathrm{E}$ were observed. Three possibilities can be considered to explain the genetic diversity of $A$. marginale from cattle on the property located in Mambaí. (1) In an endemic region for bovine anaplasmosis, the low genetic diversity of $A$. marginale has been related to a lack of vectors (RUYBAL et al., 2009).

outbreaks cause economic losses to the livestock industry (VIDOTTO et al., 1998; KOCAN et al., 2010). However, studies are lacking on the $A$. marginale strains that circulate among cattle 


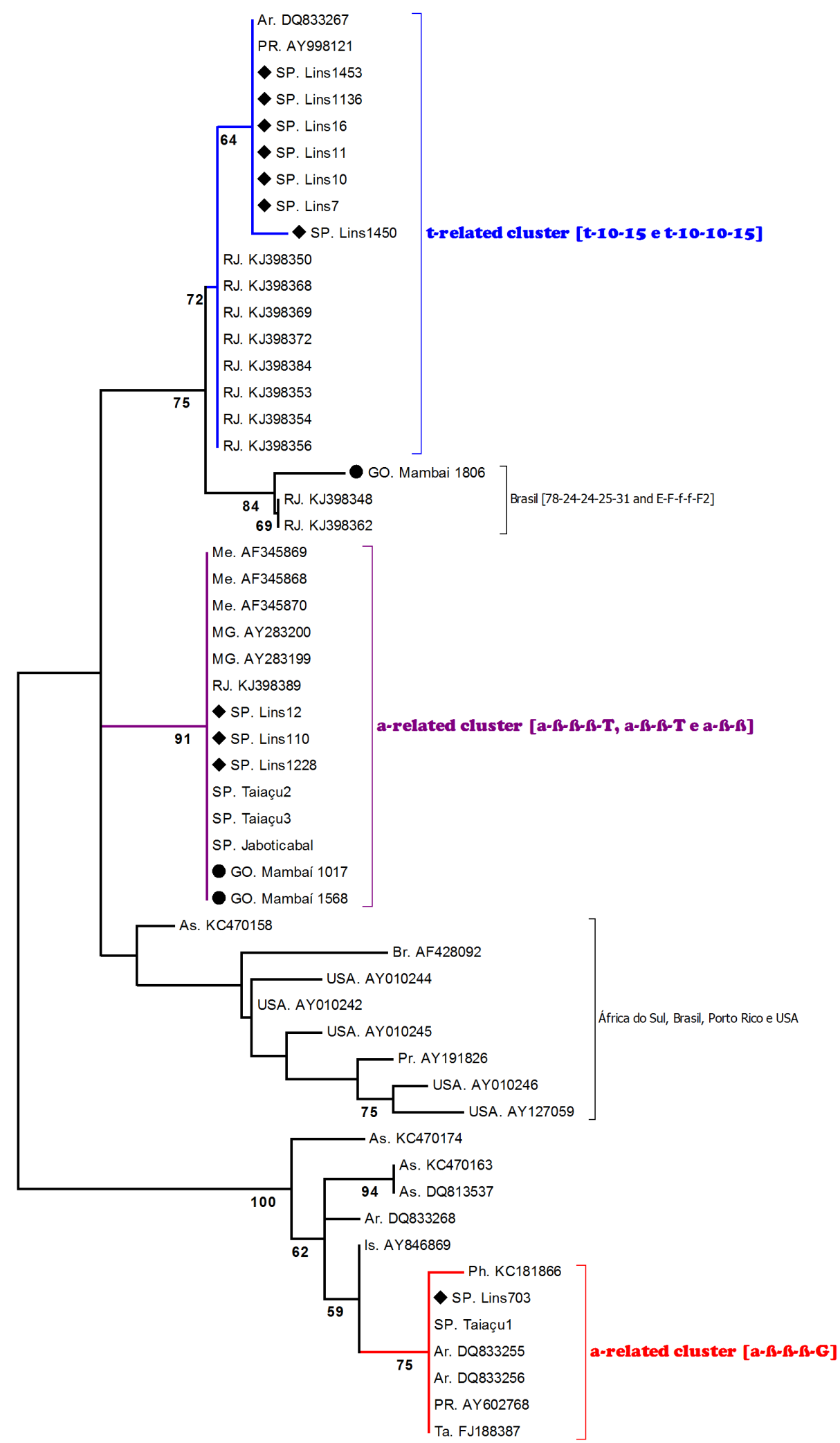

Figure 3. Characterization of $A$. marginale MSP1a sequences. Neighbor-joining phylogenetic tree of Anaplasma marginale MSP1a. The tree was constructed using the neighbor-joining method with $A$. marginale MSP1a sequences from strains identified in in dairy cattle in the states of São Paulo and Goiás, Brazil. Bootstrap values are represented as percent on internal branches (1,000 replicates). The strains $\tau-10-15$, $\alpha-\beta 2$, $\alpha-\beta 3-13, \alpha-\beta 2-192, \alpha-\beta-100,193-\beta-100,191-13-\Gamma, 191-13-18, \alpha-\beta^{3}-\Gamma$ and $\mathrm{E}-\mathrm{F}-\varphi^{2}-\mathrm{F}^{2}$ are shown, as well as the $A$. marginale strains from cattle isolated in Minas Gerais (MG), Paraná (PR), São Paulo (SP), Rio de Janeiro (RJ), South Africa (SA), Argentina (Ar), the United States (USA), the Philippines (Ph), Israel (Is), Mexico (Me), Puerto Rico (Pr) and Taiwan (Ta). The strains isolated from cattle are identified as in the legend of the figure. The MSP1a GenBank accession numbers of the respective sequences used in the phylogenetic tree are shown. 
The animals from Mambaí had been subjected to an intensive tick control program, and they were free of ticks prior to the anaplasmosis outbreak. Thus, genetic diversity is likely low in cattle herds with a low level of infestation by tick vectors and where transmission occurs through bloodsucking flies. (2) Furthermore, cattle transfers between different geographic regions are an important source of dispersion of different $A$. marginale strains (FUENTE et al., 2007). However, the herd from Mambaí was a closed herd; that is, there were no new animal introductions into the herd, and the replacement heifers were chosen from the no infected calves born on the property. (3) Furthermore, herds infected by $A$. marginale for long periods exhibit high genetic diversity in the strains of this rickettsia (PALMER et al., 2001). Thus, the first and third possibilities seem to be the more applicable to animals on the property located in Mambaí. The transmission of $A$. marginale by $R$. (B.) microplus into this herd was a recent event, and the transmission was maintained by bloodsucking flies, which resulted in low genetic diversity.

Our results showed that the genetic diversity of $A$. marginale was high in the cattle from the property located in the municipality of Lins, and nine different strains and two genotypes were identified. The results found in Lins are similar to those reported by Pohl et al. (2013) from cattle sampled in Belo Horizonte, state of Minas Gerais, southeastern Brazil, in which eight different strains of $A$. marginale and four different genotypes ( $\mathrm{B}, \mathrm{D}, \mathrm{E}$ and $\mathrm{G}$ ) were observed in the 13 samples sequenced. In our study, the high diversity of $A$. marginale in cattle from Lins, state of São Paulo, is most likely a consequence of different transmission mechanisms (biological and mechanical), each contributing to the genetic diversity of $A$. marginale in the herd. On both properties, despite acaricides were routinely used for controlling ticks and flies, infestation of the herd by these arthropods were reported even after treatment. Therefore, the occurrence of two independent transmission mechanisms (mechanical and biological) reflects a population with high genetic diversity in endemic areas (FUENTE et al., 2001). This same hypothesis was investigated in endemic regions by Silva et al. (2015a) in Brazil, where the animals were infected with multiple $A$. marginale strains. In the southeast and central-western regions of Brazil, where the present study was conducted, the tick $R$. (B.) microplus completes three to five generations per year (KASAI et al., 2000) and may, over time and during the feeding process, transmit new $A$. marginale strains to the cattle.

The prevalence of the $\mathrm{C}, \mathrm{D}, \mathrm{E}$ and $\mathrm{H}$ genotypes of $A$. marginale observed in the present study may indicate better adaptation by these genotypes, which has allowed for more efficient infection of the host. The genotypes identified in the present study have a dinucleotide tandem repeats between the Shine-Dalgarno sequence and the starting amino acid (SD-ATG) of 19, 21, 23 and 25 nucleotides. Estrada-Peña et al. (2009) evaluated the distribution of nine different genotypes in four distinct ecosystems worldwide and observed that the genotype $\mathrm{E}$ is the most common in South America, especially in Brazil and Argentina. However, the genotypes B, C, D and G have also been described previously in Brazil and Argentina (FUENTE et al., 2004; VIDOTTO et al., 2006;
POHL et al., 2013; SILVA et al., 2015a, b). The present study describes for the first time the presence of the $\mathrm{H}$ genotype in Brazil.

The $\tau-10-15$ and $\alpha-\beta^{3}-\Gamma$ strains were dominant in cattle sampled on the properties located in Lins and Mambaí, respectively. The $\tau-10-15$ strain previously had been described in cattle from Brazil (VIDOTTO et al., 2006; SILVA et al., 2015a, b), and the strain $\alpha-\beta^{3}-\Gamma$ had been detected in cattle in Argentina (RUYBAL et al., 2009), Mexico (ALMAZÁN et al., 2008), Taiwan (CABEZAS-CRUZ et al., 2013) and Brazil (SILVA et al., 2015b), countries where bovine anaplasmosis is an endemic disease. In the present study, the most commonly observed tandem repeats of the MSP1a were $\alpha, \beta$ and $\tau$. These results support previous studies on the $A$. marginale strains that circulate in South America, which show the most common tandem repeats are 4, 8, 16, 56, $60,64,67, \alpha, \beta, \gamma, \pi$ and $\tau$ (ESTRADA-PEÑA et al., 2009; SILVA et al., 2015a, b). In addition, for the isolates described from South America, the most common tandem repeats in the first repetition are 4, 16, 72, $\alpha$ and $\tau$ in Brazil (VIDOTTO et al., 2006; POHL et al., 2013; SILVA et al., 2015a, b) and $\alpha, \tau$ and B in Argentina (RUYBAL et al., 2009). Previous studies have associated the presence of the strain $\alpha-\beta^{3}-\Gamma$ with the occurrence of clinical anaplasmosis in Mexico (ALMAZÁN et al., 2008) and Brazil (SILVA et al., 2015b); however, the present study is the first that associates the occurrence of the $\tau-10-15$ strain with animal mortality. Thus, we believe that the $A$. marginale strains $\tau-10-15$ and $\alpha-\beta^{3}-\Gamma$ may be involved in the occurrence of bovine anaplasmosis outbreaks in endemic areas.

When we compared the repeated sequences found in the A. marginale samples evaluated in the present study with sequences already known (CABEZAS-CRUZ et al., 2013), we identified three new repeated sequences. The tandem repeats 191 and $\tau$ differed only by the amino acid located in position 28 . In contrast, the tandem repeats 192 and $\Gamma$ differed only by the amino acid located at position 13, and the tandem repeats 193 and 4 differed by two amino acids located at positions 5 and 18. These findings suggest that the tandem repeats 191, 192 and 193 may have evolved recently from the $\tau, \Gamma$ and 4 tandem repeats, providing evidence for increased genetic diversity of $A$. marginale in cattle. Following this hypothesis, the phylogenetic analysis based on the MSP1a sequences indicated that the strains Lins 11 (191-13-18), Lins 1453 (191-13-Г) and Lins 1450 (193- $\beta-100)$ possibly evolved from the strain $\tau-10-15$, whereas Lins $703\left(\alpha-\beta^{2}-192\right)$ evolved from the strain $\alpha-\beta^{3}-\Gamma$.

Considering that in certain regions ticks might not play an important role in transmitting $A$. marginale between cattle, the strains most commonly found in these regions might be transmitted mechanically. The negatively charged amino acids, aspartate (D) and glutamic acid (E), at position 20 are critical for the interaction of the cell of the invertebrate host with the MSP1a of $A$. marginale (FUENTE et al., 2003a). These amino acids affect the secondary structure of MSP1a, which seems to affect the transmission of A. marginale by ticks (CABEZAS-CRUZ et al., 2013). In agreement with these results, $50 \%$ of the tandem repeats of the MSP1a of $A$. marginale obtained in the present study had the amino acid glycine $(\mathrm{G})$ at position 20 . Thus, in the two studied herds, 
the circulating $A$. marginale strains can be transmitted by both mechanisms: biologically and mechanically.

\section{Conclusion}

The $\tau-10-15$ and $\alpha-\beta^{3}-\Gamma$ strains were predominantly associated with the occurrence of clinical anaplasmosis in calves from southeastern Brazil, whereas the $\alpha-\beta^{3}-\Gamma$ strain was predominantly associated with mortality of calves, heifers and lactating cows in central-western, Brazil. In addition to the occurrence of clinical anaplasmosis, we also observed high rickettsemia and low serological prevalence of $A$. marginale. The genetic diversity of MSP1a was low in cattle from the municipality of Mambaí, where animals died due to anaplasmosis, and high in animals from the municipality of Lins, where the animals did not die but had drastic reduction in milk production. One of the factors that likely contributed to the occurrence of clinical anaplasmosis in the studied herds may be the low population of ticks and bloodsucking flies, which may have reduced the levels of antibodies and the responsiveness of the cattle to $A$. marginale.

\section{References}

Almazán C, Medrano C, Ortiz M, Fuente J. Genetic diversity of Anaplasma marginale strains from an outbreak of bovine anaplasmosis in an endemic area. Vet Parasitol 2008; 158(1-2): 103-109. http://dx.doi.org/10.1016/j. vetpar.2008.08.015. PMid:18842342.

Andrade GM, Machado RZ, Vidotto MC, Vidotto O. Immunization of bovines using a DNA vaccine (pcDNA3.1/MSP1b) prepared from the Jaboticabal strain of Anaplasma marginale. Ann NYAcad Sci 2004; 1026(1): 257-266. http://dx.doi.org/10.1196/annals.1307.040. PMid:15604503.

Anisimova M, Gascuel O. Approximate likelihood-ratio test for branches: a fast, accurate, and powerful alternative. Syst Biol 2006; 55(4): 539-552. http://dx.doi.org/10.1080/10635150600755453. PMid:16785212.

Aubry P, Geale DW. A review of bovine anaplasmosis. Transbound Emerg Dis 2011; 58(1): 1-30. http://dx.doi.org/10.1111/j.1865-1682.2010.01173.x. PMid:21040509.

Bowie MV, Fuente J, Kocan KM, Blouin EF, Barbet AF. Conservation of major surface protein 1 genes of Anaplasma marginale during cyclic transmission between ticks and cattle. Gene 2002; 282(1-2): 95-102. http://dx.doi.org/10.1016/S0378-1119(01)00845-9. PMid:11814681.

Cabezas-Cruz A, Passos LMF, Lis K, Kenneil R, Valdés JJ, Ferrolho $\mathrm{J}$, et al. Functional and immunological relevance of Anaplasma marginale major surface protein 1a sequence and structural analysis. PLoS One 2013; 8(6): e65243. http://dx.doi.org/10.1371/journal.pone.0065243. PMid:23776456.

Carelli G, Decaro N, Lorusso A, Elia G, Lorusso E, Mari V, et al. Detection and quantification of Anaplasma marginale DNA in blood samples of cattle by real-time PCR. Vet Microbiol 2007; 124(1-2): 107-114. http:// dx.doi.org/10.1016/j.vetmic.2007.03.022. PMid:17466470.

Castresana J. Selection of conserved blocks from multiple alignments for their use in phylogenetic analysis. Mol Biol Evol 2000; 17(4): 540-552. http://dx.doi.org/10.1093/oxfordjournals.molbev.a026334. PMid:10742046.

Chevenet F, Brun C, Bañuls AL, Jacq B, Christen R. TreeDyn: towards dynamic graphics and annotations for analyses of trees. $B M C$
Bioinformatics 2006; 7(1): 439. http://dx.doi.org/10.1186/1471-21057-439. PMid:17032440.

Delport W, Poon AF, Frost SD, Kosakovsky Pond SL. Datamonkey 2010: a suite of phylogenetic analysis tools for evolutionary biology. Bioinformatics 2010; 26(19): 2455-2457. http://dx.doi.org/10.1093/ bioinformatics/btq429. PMid:20671151.

Dumler JS, Barbet AF, Bekker CPJ, Dasch GA, Palmer GH, Ray SC, et al. Reorganization of genera in the families Rickettsiaceae and Anaplasmataceae in the order Rickettsiales: unification of some species of Ehrlichia with Anaplasma, Cowdria with Ehrlichia and Ehrlichia with Neorickettsia, descriptions of six new species combinations and designation of Ehrlichia equi and 'HGE agent' as subjective synonyms of Ehrlichia phagocytophila. Int J Syst Evol Microbiol 2001; 51(6): 2145-2165. http:// dx.doi.org/10.1099/00207713-51-6-2145. PMid:11760958.

Edgar RC. MUSCLE: multiple sequence alignment with high accuracy and high throughput. Nucleic Acids Res 2004; 32(5): 1792-1797. http:// dx.doi.org/10.1093/nar/gkh340. PMid:15034147.

Estrada-Peńa A, Naranjo V, Acevedo-Whitehouse K, Mangold AJ, Kocan KM, Fuente J. Phylogeographic analysis reveals association of tick-borne pathogen, Anaplasma marginale, MSP1a sequences with ecological traits affecting tick vector performance. BMC Biol 2009; 7(1): 57. http://dx.doi. org/10.1186/1741-7007-7-57. PMid:19723295.

Felsenstein J. PHYLIP: Phylogeny Inference Package (Version 3.2). Cladistics 1989; 5(1): 164-166.

Fuente J, Van Den Bussche RA, Prado TM, Kocan KM. Anaplasma marginale msp la genotypes evolved under positive selection pressure but are not markers for geographic isolates. J Clin Microbiol 2003a; 41(4): 1609-1616. http://dx.doi.org/10.1128/JCM.41.4.1609-1616.2003. PMid:12682152.

Fuente J, Garcia-Garcia JC, Blouin EF, Kocan KM. Characterization of the functional domain of major surface protein 1a involved in adhesion of the rickettsia Anaplasma marginale to host cells. Vet Microbiol 2003b; 91(2-3): 265-283. http://dx.doi.org/10.1016/S0378-1135(02)00309-7. PMid:12458174.

Fuente J, Garcia-Garcia JC, Blouin EF, Rodríguez SD, García MA, Kocan KM. Evolution and function of tandem repeats in the major surface protein 1a of the ehrlichial pathogen Anaplasma marginale. Anim Health Res Rev 2001; 2(2): 163-173. PMid:11831437.

Fuente J, Passos LMF, Van Den Bussche RA, Ribeiro MFB, Facury Filho EJ, Kocan KM. Genetic diversity and molecular phylogeny of Anaplasma marginale isolates from Minas Gerais, Brazil. Vet Parasitol 2004; 121(3-4): 307-316. http://dx.doi.org/10.1016/j.vetpar.2004.02.021. PMid:15135871.

Fuente J, Ruybal P, Mtshali MS, Naranjo V, Shuqing L, Mangold AJ, et al. Analysis of world strains of Anaplasma marginale using major surface protein 1a repeat sequences. Vet Microbiol 2007; 119(2-4): 382-390. http://dx.doi.org/10.1016/j.vetmic.2006.09.015. PMid:17084044.

Garcia-Garcia JC, Fuente J, Kocan KM, Blouin EF, Halbur T, Onet $\mathrm{VC}$, et al. Mapping of B-cell epitopes in the $\mathrm{N}$-terminal repeated peptides of Anaplasma marginale major surface protein 1a and characterization of the humoral immune response of cattle immunized with recombinant and whole organism antigens. Vet Immunol Immunopathol 2004; 98(3-4): 137151. http://dx.doi.org/10.1016/j.vetimm.2003.11.003. PMid:15010223.

Kasai N, Labruna MB, Pires AV, Louvandini H, Abdalla AL, Gennari SG. Dinâmica populacional de Boophilus microplus (Canestrini, 1887) em bovinos leiteiros mantidos em manejo de pastejo rotativo de capimelefante. Arq Bras Med Vet Zootec 2000; 52(5): 453-458. http://dx.doi. org/10.1590/S0102-09352000000500008. 
Kocan KM, Fuente J, Blouin EF, Coetzee JF, Ewing SA. The natural history of Anaplasma marginale. Vet Parasitol 2010; 167(2-4): 95-107. http://dx.doi.org/10.1016/j.vetpar.2009.09.012. PMid:19811876.

Lew AE, Bock RE, Minchin CM, Masaka S. A msp1a polymerase chain reaction assay for specific detection and differentiation of Anaplasma marginale isolates. Vet Microbiol 2002; 86(4): 325-335. http://dx.doi. org/10.1016/S0378-1135(02)00017-2. PMid:11955782.

Machado RZ, Montassier HJ, Pinto AA, Lemos EG, Machado MRF, Valadão IFF, et al. An enzyme-linked immunosorbent assay (ELISA) for the detection on antibodies against Babesia bovis in cattle. Vet Parasitol 1997; 71(1): 17-26. http://dx.doi.org/10.1016/S0304-4017(97)000034. PMid:9231985.

Palmer GH, Rurangirwa FR, McElwain TF. Strain composition of the Ehrlichia Anaplasma marginale within persistently infected cattle, a mammalian reservoir for tick transmission. J Clin Microbiol 2001; 39(2): 631-635. http://dx.doi.org/10.1128/JCM.39.2.631-635.2001. PMid:11158120.

Pohl AE, Cabezas-Cruz A, Ribeiro MFB, Silveira JAG, Silaghi C, Pfister $\mathrm{K}$, et al. Detection of genetic diversity of Anaplasma marginale isolates in Minas Gerais, Brazil. Rev Bras Parasitol Vet 2013; 22(1): 129-135. http:// dx.doi.org/10.1590/S1984-29612013000100024. PMid:24252959.
Ruybal P, Moretta R, Perez A, Petrigh R, Zimmer P, Alcaraz E, et al. Genetic diversity of Anaplasma marginale in Argentina. Vet Parasitol 2009; 162(1-2): 176-180. http://dx.doi.org/10.1016/j.vetpar.2009.02.006. PMid:19285808.

Silva JB, André MR, Machado RZ. Low genetic diversity of Anaplasma marginale in calves in an endemic area for bovine anaplasmosis in the state of São Paulo, Brazil. Ticks Tick Borne Dis 2015b; (in press) PMid:26318264.

Silva JB, Gonçalves LR, Varani AM, André MR, Machado RZ. Genetic diversity and molecular phylogeny of Anaplasma marginale studied longitudinally under natural transmission conditions in Rio de Janeiro, Brazil. Ticks Tick Borne Dis 2015a; 6(4): 499-507. http://dx.doi. org/10.1016/j.ttbdis.2015.04.002. PMid:25985719.

Vidotto MC, Kano SF, Gregori F, Headley SA, Vidotto O. Phylogenetic analysis of Anaplasma marginale strains from Paraná State, Brazil, using the msp 1-alfa and msp4 genes. J Vet Med B Infect Dis Vet Public Health 2006 53(9): 404-411. http://dx.doi.org/10.1111/j.1439-0450.2006.00984.x. PMid:17062116.

Vidotto MC, Vidotto O, Andrade GM, Palmer G, McElwain T, Knowles DP. Seroprevalence of Anaplasma marginale in cattle in Paraná State, Brazil, by MSP-5 competitive ELISA. Ann NY Acad Sci 1998; 849(1): 424-426. http://dx.doi.org/10.1111/j.1749-6632.1998.tb11087.x. PMid:9668503. 